\title{
Essential Oils and Isolated Terpenes in Nanosystems Designed for Topical Administration: A Review
}

\author{
Sheila P. de Matos ${ }^{1}$, Helder F. Teixeira ${ }^{1}$, Ádley A. N. de Lima ${ }^{2}$, Valdir F. Veiga-Junior ${ }^{3}{ }^{\circledR D}$ and \\ Letícia S. Koester 1 ,* \\ 1 Programa de Pós-Graduação em Ciências Farmacêuticas, Faculdade de Farmácia, Universidade Federal do \\ Rio Grande do Sul, Av. Ipiranga, 2752, Porto Alegre 90610-000, Brazil; sheilaporto@outlook.com (S.P.d.M.); \\ helder.teixeira@ufrgs.br (H.F.T.) \\ 2 Programa de Pós-Graduação em Ciências Farmacêuticas, Departamento de Farmácia, Universidade Federal \\ do Rio Grande do Norte, Av. General Cordeiro de Farias, s/n, Petrópolis, Natal 59012-570, Brazil; \\ adleyantonini@yahoo.com.br \\ 3 Departamento de Engenharia Química, Instituto Militar de Engenharia, Praça Gen. Tibúrcio, 80, \\ Praia Vermelha, Urca, Rio de Janeiro 22290-270, Brazil; valdir.veiga@gmail.com \\ * Correspondence: leticia.koester@ufrgs.br; Tel.: +55-51-3308-5278
}

Received: 8 March 2019; Accepted: 2 April 2019; Published: 5 April 2019

\begin{abstract}
Essential oils are natural products with a complex composition. Terpenes are the most common class of chemical compounds present in essential oils. Terpenes and the essential oils containing them are widely used and investigated by their pharmacological properties and permeation-enhancing ability. However, many terpenes and essential oils are sensitive to environmental conditions, undergoing volatilization and chemical degradation. In order to overcome the chemical instability of some isolated terpenes and essential oils, the encapsulation of these compounds in nanostructured systems (polymeric, lipidic, or molecular complexes) has been employed. In addition, nanoencapsulation can be of interest for pharmaceutical applications due to its capacity to improve the bioavailability and allow the controlled release of drugs. Topical drug administration is a convenient and non-invasive administration route for both local and systemic drug delivery. The present review focuses on describing the current status of research concerning nanostructured delivery systems containing isolated terpenes and/or essential oils designed for topical administration and on discussing the use of terpenes and essential oils either for their biological activities or as permeation enhancers in pharmaceutic formulations.
\end{abstract}

Keywords: essential oils; terpenes; nanotechnology; cyclodextrins; topical drug administration

\section{Introduction}

Essential oils (EO) are natural products extracted by hydrodistillation from plant materials, composed by small, volatile, and fairly hydrophobic molecules [1-3]. The functions of EO in plant organisms seem to be related to environmental interactions and protection of the plant against predators and pathogens $[1,4,5]$. In the industry, essential oils are materials of great interest with a wide range of possible applications in the nutritional, agricultural, cosmetic, and pharmaceutical fields [6,7], due to their broad spectra of biological activities such as antimicrobial, repellent, analgesic, anti-inflammatory activity, and many others [1,2]. Essential oils can be extracted from plant matrices using different techniques classified as classical/conventional (that use water distillation by heat as a means to extract the whole volatile material) and innovative/advanced (which focus on the improvement of selectivity in extraction efficiency by reducing extraction time, use of energy, solvent, and $\mathrm{CO}_{2}$ emissions) [1].

Terpenes and terpenoids (the oxygenated derivatives of terpenes [2]) are the chemical compounds representing the majority of molecules in essential oil composition [8]. This class of molecules is 
characterized by the combination of isoprene units $\left(\mathrm{C}_{5} \mathrm{H}_{8}\right)$. Terpenes can be classified according to the number of isoprene units in their structure (e.g., hemiterpenes are formed by one isoprene unit, monoterpenes are formed by two isoprene units, sesquiterpenes by three isoprene units, and diterpene formed by four units) [2,8]. Smaller terpenes, up to three isoprene units, are highly volatile, and the volatility decreases with an increased number of isoprene units [9]. Many biological activities of terpenes and terpenoids are described in the literature, being this class of molecules a valuable source of therapeutic agents with pharmaceutical applications, such as anti-inflammatory [10], wound healing [11], antineoplastic applications [12-14]. In addition, some compounds of the class are widely investigated and reported as penetration enhancers for percutaneous drug delivery, being used as excipients in the preparation of nanostructured systems $[7,8,15]$. Smaller terpenes are usually thermolabile and susceptible to volatilization and degradation, mainly by oxidation and isomerization $[6,16]$.

The topical administration of drugs consists in the localized administration of formulations to an organism, comprising dermal and mucosal administrations (e.g., ocular, vaginal, nasal, and rectal routes). Among those, the most widely employed is the cutaneous route, which may be attributed to the easiness of access compared to other topic routes [17]. When applied to the skin, a drug delivery system can be considered dermal (when the targeting site of the drug is the skin) or transdermal (when the drug needs to pass through skin layers in order to reach its target); for mucosal tissue administration, delivery can be mucosal and transmucosal [18]. Many issues concerning these delivery routes are described in the literature, such as the resistance to diffusion through the skin and mucosae when aiming towards transdermal or transmucosal delivery and the reduced contact of the formulation with mucosal tissues due to mucus and, thus, reduced drug bioavailability $[19,20]$.

Encapsulation of essential oils in micro or nanometric systems is an interesting strategy to provide better stability to the volatile compounds and protect them against environmental factors that may cause chemical degradation $[2,6]$. In addition, the encapsulation in nanometric systems may improve the bioavailability and bioefficacy of formulations as a result of cellular absorption and provide controlled release of bioactive compounds $[3,21]$. Special nanostructured systems have been designed intending topical administration as approaches to overcome the drawbacks inherent to these administration routes, such as mucoadhesive systems that prolong the contact with mucosae and systems that favor the passage of the drug trough skin or mucosal tissue layers [20,22]. Molecular encapsulation through complexation with cyclodextrins is another strategy employed to improve the stability of essential oil components, avoid volatilization (and, consequently, prolonging contact,) and enhance permeation of the bioactive molecules [23].

In recent decades, the interest in nanotechnological approaches and use of natural products have raised great attention in the search and development of drug delivery systems. The present review intends to assess the panorama of research using nanostructured delivery systems containing essential oils and/or their isolated terpenes/terpenoids as bioactive compounds and/or excipients for topical administration routes.

\section{Literature Survey}

A literature survey was carried out in three different databases: Embase, Scopus, and Pubmed. Initially, all results found until 31 December 2018 were considered, without limiting the search period before this date. The search terms used were a combination of words related to nanostructured systems "AND" terpenes/essential oils "AND" topical administration route. All classes of terpenes were included, not only low-volatile terpenes, as well as all topical administration routes, which comprise cutaneous and mucosal administration. Database search lines can be found in Supplementary Materials, Table S1.

The number of results obtained using Scopus were 87, those from Embase were 365, and those from PubMed were 64. Among those results, only research articles in English were considered for data screening. Also, duplicates were disregarded. In addition, reference lists of papers were screened to 
detect research papers which did not appear in the database research but might fulfill the acceptance criteria (Figure 1). Afterwards, the papers were screened and selected if meeting the following acceptance criteria:

- Original research data.

- Use of essential oil containing terpenes and/or isolated terpenes in nanostructured systems or cyclodextrins.

- Formulations for topical administration.

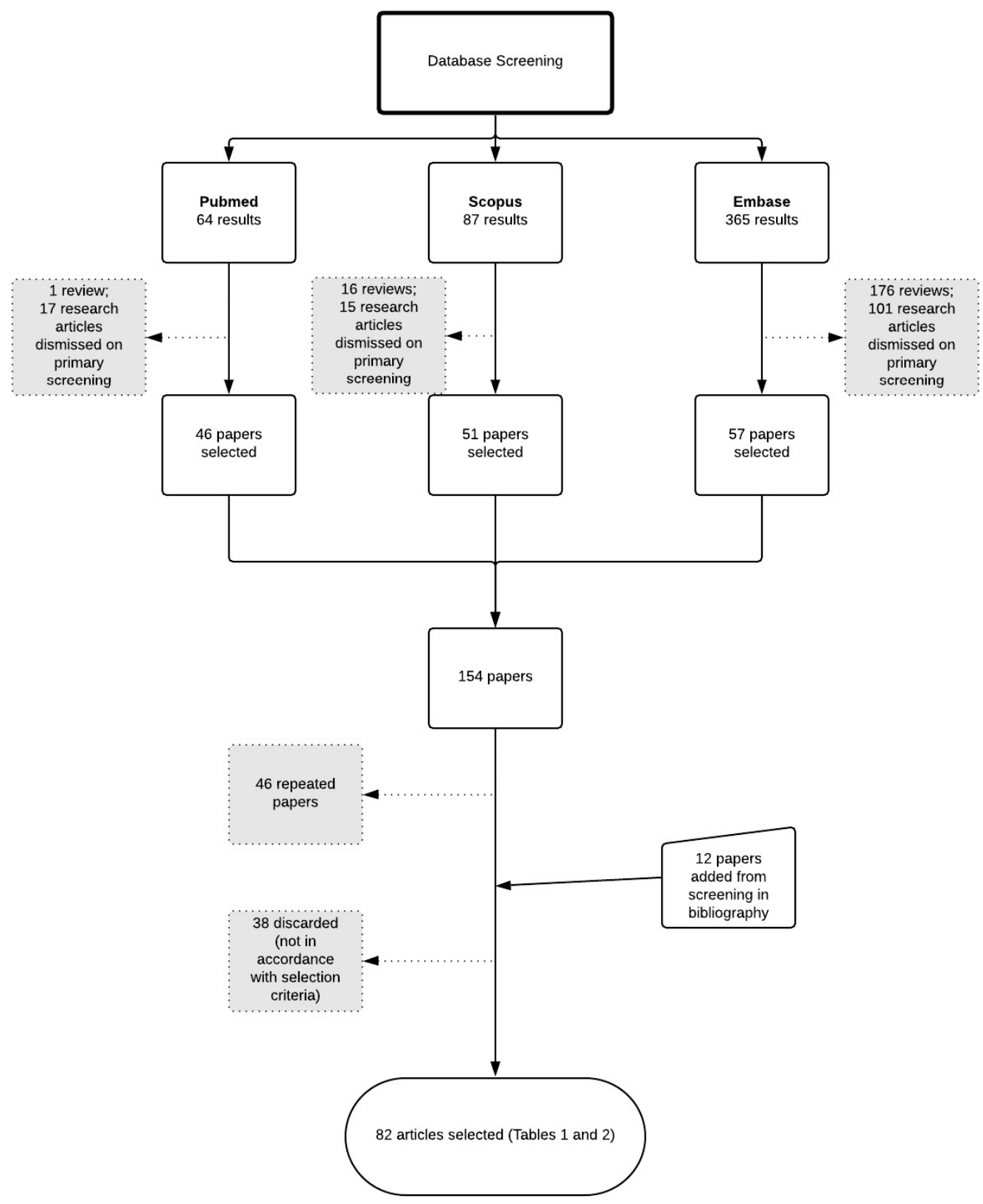

Figure 1. Flowchart representing the steps of literature survey and selection of research papers.

Finally, 82 papers were selected for further data extraction. Studies were sorted by year of publication in order to visualize the evolution of research in this field over the years (Figure 2). The first report dated from 1989 and was by Saettone et al. [24], who studied the complexation of the diterpene forskolin with cyclodextrin for ocular administration. The number of publications has gradually grown over the years, indicating an increasing interest in the topic. 


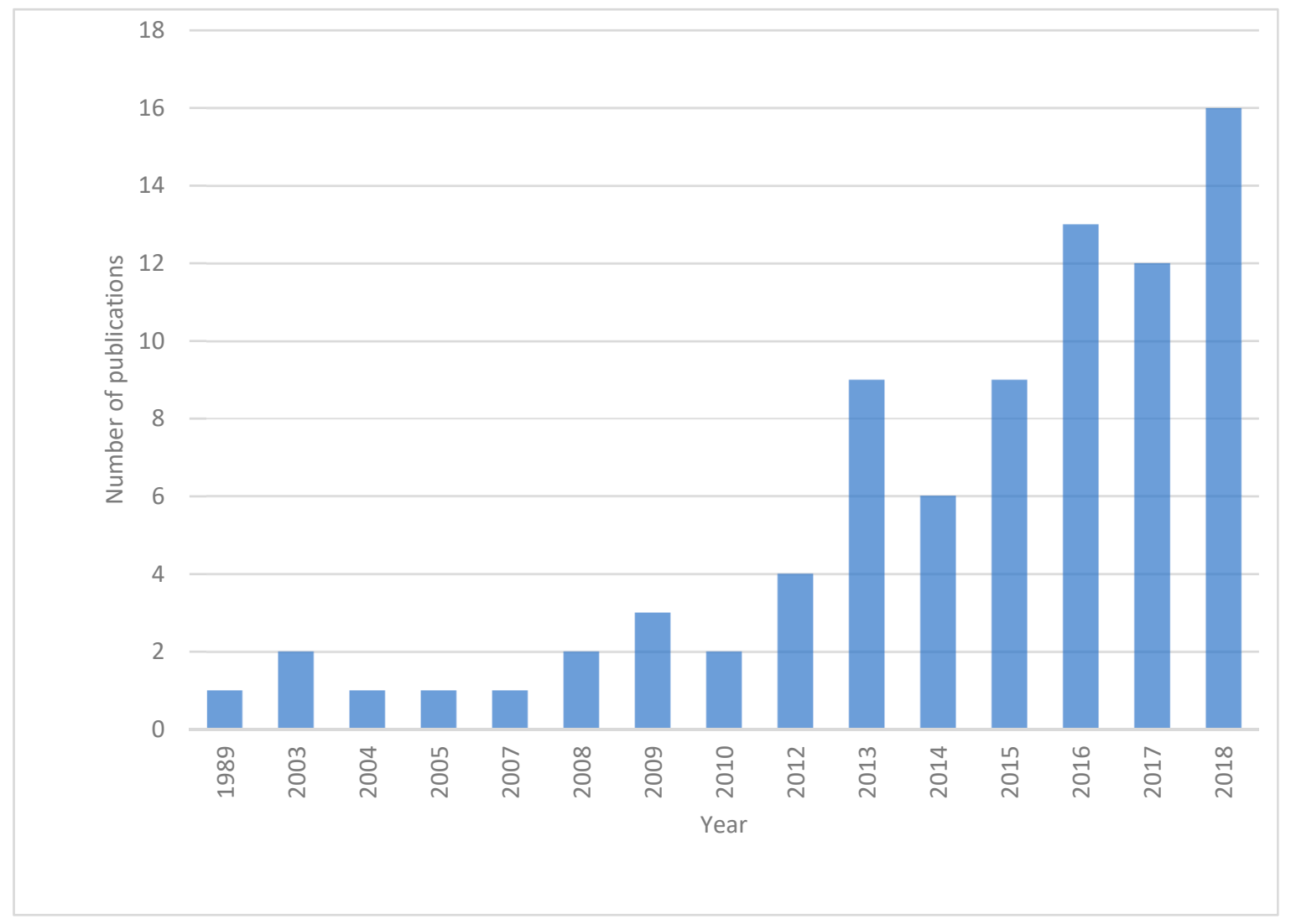

Figure 2. Annual distribution of publications.

Data concerning the essential oil or terpene used, encapsulation system, nanosystem preparation technique, administration route of formulation, and use of EO/terpene as bioactive compounds or excipients were extracted from the selected papers and compiled in Tables 1 and 2 in order to ease the access to the extracted data, which are further discussed in the following sections of this review.

\section{Discussion}

\subsection{Topical Administration Routes}

Topical drug administration can be described as the localized application of a pharmaceutical dosage form and comprises both dermal and mucosal administration $[19,20]$. In Figure 3, the different sites of administration for nanosystems containing isolated terpenes and/or EO are shown. It can be noticed that among the study formulations containing nanoencapsulated EO and/or terpenes, dermal and transdermal administration represent nearly $90 \%$ of the administration routes, which can be attributed to the non-invasiveness, convenience, and painless qualities of this type of administration.

Dermal administration of nanostructured systems containing terpenes and EO is, in general, mainly used as a treatment for conditions localized on the skin surface, such as for wound healing, and to vehiculate anti-inflammatory, antimicrobial, and repellent agents. On the other hand, transdermal delivery is employed in cases where the bioactive compound needs to reach deeper layers of the skin or even the systemic circulation, such as for anesthetic, antihypertensive, and antidiabetic drugs (Tables 1 and 2).

Mucosal administration (ocular, nasal, oral, vaginal) still represents a challenging route due to the presence of mucus, lacrimal fluids, and saliva, which can impair the bioavailability of the bioactive compound [19]. However, it is possible to foresee the development of mucoadhesive formulations as means to overcome these limitations. 
Table 1. Publications found in the literature concerning the encapsulation of isolated terpenes in nanostructured systems intended for topical administration

\begin{tabular}{|c|c|c|c|c|c|c|}
\hline & Year & Terpene & System & $\begin{array}{c}\text { Administration } \\
\text { Route }\end{array}$ & Biological Activity & $\begin{array}{l}\text { Terpene Role in the } \\
\text { Nanosystem }\end{array}$ \\
\hline [25] & 2018 & $\begin{array}{l}\text { Limonene, cineole, } \\
\text { fenchone, and citral }\end{array}$ & Invasomes & Cutaneous & Anti-acne & Excipient \\
\hline [26] & 2018 & $\begin{array}{l}\text { Ursolic acid } \\
\text { Unolt }\end{array}$ & Solid lipid nanoparticles & Cutaneous & Antiarthritic & Bioactive \\
\hline [27] & 2018 & Limonene & Nanovesicles & Transdermal & Antineoplastic & Excipient \\
\hline [28] & 2018 & Paeoniflorin & Ethosomes & Transdermal & Antiarthritic & Bioactive \\
\hline [29] & 2018 & Rebaudioside A & Ultra-small micelles & Ocular & NA & Excipient \\
\hline [30] & 2018 & Farnesol & Nanoparticles & Oral & Antibiofilm & Bioactive \\
\hline [31] & 2018 & Eucaliptol & Nanoemulsion & Transfollicular & NA & Excipient \\
\hline [32] & 2018 & Menthol & Nanoparticles & Transdermal & Osteoporosis treatment & Excipient \\
\hline [33] & 2018 & Tripterine & Phytosomes & Oral & Antineoplastic & Bioactive \\
\hline [34] & 2018 & Ursolic acid and anethole & Liposomes & Nasal & Antineoplastic & Bioactive and excipient \\
\hline [10] & 2018 & Thymol & Solid lipid nanoparticles & Cutaneous & Anti-inflammatory & Bioactive \\
\hline [35] & 2018 & Docetaxel & Polymeric nanoparticles & Nasal & Antineoplastic & Bioactive \\
\hline [36] & 2018 & Forskolin & Nanostructures lipid carriers & Transdermal & Photoprotector & Bioactive \\
\hline [37] & 2017 & Citral and limonene & Transferosomes and liposomes & Transdermal & Antiarthritic & Excipient \\
\hline [38] & 2017 & Paeoniflorin & Glycerosomes & Transdermal & Anti-inflammatory & Bioactive and Excipient \\
\hline [39] & 2017 & Limonene & Transinvasomes & Transdermal & NA & Excipient \\
\hline [40] & 2017 & Limonene & PEGylated liposomes & Transdermal & Alzheimer's treatment & Excipient \\
\hline [41] & 2017 & Triptolide & Nanoemulsion & Percutaneous & Anti-inflammatory and analgesic & Bioactive \\
\hline [42] & 2017 & $\beta$-citronellene & Invasomes & Transdermal & Hypertension treatment & Excipient \\
\hline [43] & 2017 & $\alpha$-bisabolol & Nanocapsules & Ocular & Antinociceptive & Bioactive \\
\hline [11] & 2017 & Hyperforin & Hydroxypropyl- $\beta$-cyclodextrin & Cutaneous & Wound healing & Bioactive \\
\hline [44] & 2016 & Cineole and limonene & Penetration enhancer vehicle & Transdermal & Antifungal & Excipient \\
\hline [45] & 2016 & $\beta$-citronellene & Invasomes & Transdermal & Hypertension treatment & Excipient \\
\hline [46] & 2016 & Squalene & Solid nanoemulsion & Transdermal & Immunization & Excipient \\
\hline [14] & 2016 & Paclitaxel & Solid Lipid Nanoparticles & Cutaneous & Antineoplastic & Bioactive \\
\hline [47] & 2016 & Madecassoside & Liposomes & Cutaneous & Wound healing & Bioactive \\
\hline [48] & 2016 & Asiaticoside & Nanofibers & Cutaneous & Wound healing & Bioactive \\
\hline [49] & 2016 & Triterpenoids of Ganoderma $l$. & Nanogel & Cutaneous & Frostbite treatment & Bioactive \\
\hline [50] & 2016 & Safranal & Nanoemulsion & Nasal & Cerebral ischemia treatment & Bioactive \\
\hline [51] & 2015 & Ursolic acid & Niosomal gel & Transdermal & Antiarthritic & Bioactive \\
\hline [52] & 2015 & Farnesol & Polymeric nanoparticles & Oral & Antibiofilm & Bioactive \\
\hline [53] & 2015 & Ursolic acid and oleanoic acid & Nanoemulsion & Cutaneous & Anti-inflammatory & Bioactive \\
\hline [13] & 2015 & Docetaxel & Nanofibers & Cutaneous & Antineoplastic & Bioactive \\
\hline [54] & 2014 & Limonene & Nanoemulsion & Transdermal & NA & Excipient \\
\hline [55] & 2014 & Limoneno & PEGilated liposomes & Transdermal & NA & Excipient \\
\hline
\end{tabular}


Table 1. Cont

\begin{tabular}{|c|c|c|c|c|c|c|}
\hline & Year & Terpene & System & $\begin{array}{l}\text { Administration } \\
\text { Route }\end{array}$ & Biological Activity & $\begin{array}{l}\text { Terpene Role in the } \\
\text { Nanosystem }\end{array}$ \\
\hline [56] & 2014 & Limonene and 1,8-cineole & $\begin{array}{l}\text { Nanoemulsion and solid lipid nanoparticles } \\
\text { and nanostructures lipid carriers }\end{array}$ & Cutaneous & Cutaneous lesions treatment & Excipient \\
\hline [12] & 2014 & Paclitaxel & $\begin{array}{l}\text { Solid lipid nanoparticles and } \\
\text { Nanostructures lipid carriers }\end{array}$ & Cutaneous & Hyperkeratosis treatment & Bioactive \\
\hline [57] & 2013 & Betulin & Nanoemulsion & Cutaneous & Antineoplastic & Bioactive \\
\hline [58] & 2013 & Limonene & Nanoemulsion & Transdermal & Analgesic & Excipient \\
\hline [59] & 2013 & Astragaloside IV & Solid lipid nanoparticles & Cutaneous & Wound healing & Bioactive \\
\hline$[60]$ & 2013 & Limonene & Liposomes & Transdermal & NA & Excipient \\
\hline$[61]$ & 2013 & Lupane & Liposomes & Cutaneous & Leishmanicidal & Bioactive \\
\hline [62] & 2013 & Hurpezine A & $\begin{array}{l}\text { Solid lipid nanoparticles, Nanostructures } \\
\text { lipid carriers and Microemulsion }\end{array}$ & Transdermal & Alzheimer's treatment & Bioactive \\
\hline [63] & 2012 & Tripterine & Nanostructures lipid carriers & Cutaneous & Antineoplastic & Bioactive \\
\hline$[64]$ & 2012 & Asiaticoside & Liposomes & Transdermal & Stimulation of collagen synthesis & Bioactive \\
\hline [65] & 2010 & Triptolide & Ethosomes & Transdermal & Anti-inflammatory & Bioactive \\
\hline [66] & 2010 & Squalene & Nanostructures lipid carriers & Cutaneous & Psoriasis treatment & Excipient \\
\hline$[67]$ & 2009 & Cineole & Penetration enhancer vehicle & Transdermal & Alopecia treatment & Excipient \\
\hline [68-70] & 2009,2008 & Limonene, citral and cineole & Invasomes & Transdermal & Photosensitization & Excipient \\
\hline [71] & 2005 & Triptolide & Solid lipid nanoparticles & Cutaneous & Anti-inflammatory & Bioactive \\
\hline [72] & 2003 & Sericoside & derivates of $\beta$ - and $\gamma$-cyclodextrins & Cutaneous & Anti-inflammatory & Bioactive \\
\hline [73] & 2003 & Triptolide & Solid lipid nanoparticles & Cutaneous & Anti-inflammatory & Bioactive \\
\hline [24] & 1989 & Forskolin & $\beta$ - and $\gamma$-cyclodextrins & Ocular & $\begin{array}{l}\text { Treatment of intraocular } \\
\text { hypertension }\end{array}$ & Bioactive \\
\hline
\end{tabular}


Table 2. Publications found in the literature concerning the encapsulation of essential oils, fixed oils, and plant extract containing terpenes in nanostructured systems intended for topical administration.

\begin{tabular}{|c|c|c|c|c|c|c|}
\hline & Year & $\begin{array}{l}\text { Essential Oil/Fixed Oil/Plant } \\
\text { Extract }\end{array}$ & System & $\begin{array}{l}\text { Administration } \\
\text { Route }\end{array}$ & Biological Activity & $\begin{array}{l}\text { Essential Oil/Fixed Oil/Plant } \\
\text { Extract Role in the System }\end{array}$ \\
\hline [74] & 2018 & Lemon EO & Nanoemulsion & Cutaneous & Hyperpigmentation treatment & Excipient \\
\hline [75] & 2018 & Clove EO and sweet fennel EO & Nanoemulsion & Cutaneous & Autoimmune dermatoses & Excipient \\
\hline [76] & 2018 & Clove EO and sweet fennel EO & Nanoemulsion & Cutaneous & Autoimmune dermatoses & Excipient \\
\hline [77] & 2018 & Mentha EO & Nanogel & Vaginal & Antifungal & Bioactive \\
\hline [78] & 2018 & Nigella Sativa EO & Nanoemulsions & Cutaneous & Anti-inflammatory & Bioactive \\
\hline [79] & 2017 & Clove EO and Sweet Fennel EO & Nanoemulsion & Transdermal & Autoimmune dermatoses & Excipient \\
\hline [80] & 2017 & Cymbopogon Flexuous EO & Nanocapsules & Cutaneous & Antimicrobial & Bioactive \\
\hline [81] & 2017 & Rosemary EO & Lipid Nanoparticles & Cutaneous & Skin hydration & Bioactive \\
\hline [82] & 2017 & Eucaliptus globulosus EO & Nanosized-microemulsion & Cutaneous & Repellent & Bioactive \\
\hline [83] & 2017 & Syzygium aromaticum $\mathrm{EO}$ & Nanoemulsion & Cutaneous & Wound healing and antidermatophytic & Bioactive \\
\hline$[84]$ & 2016 & Tea Tree Oil & Nanoemulsion & Cutaneous & Antimicrobial & Bioactive \\
\hline [85] & 2016 & Centella asiatica extract & Hydroxypropyl- $\beta$-cyclodextrin & Cutaneous & Wound healing & Bioactive \\
\hline [86] & 2016 & Lippia sidoides EO & Nanogel & Oral & Periodontitis treatment & Bioactive \\
\hline [87] & 2015 & Foeniculum vulgare $\mathrm{EO}$ & Nanoemulsion & Transdermal & Antidiabetic & Bioactive \\
\hline [88] & 2015 & Lemongrass oil & Nanosponges & Cutaneous & Antifungal & Bioactive \\
\hline$[89]$ & 2015 & Copaifera multijuga $E O$ & Nanoemulsion & Percutaneous & Anti-inflammatory & Bioactive \\
\hline [90] & 2015 & Santolina insularis EO & Penetration enhancing vehicle & Percutaneous & Antimicrobial & Bioactive and excipient \\
\hline [91] & 2015 & Melaleuca alternifolia EO & Nanoemulsion and Nanocapsules & Cutaneous & Wound healing and antidermatotophytic & Bioactive \\
\hline [92] & 2014 & Eucalyptus oil & Nanoemulsion & Cutaneous & Antibacterial and Wound healing & Bioactive \\
\hline [93] & 2014 & Plai oil & Hydroxypropyl- $\beta$-cyclodextrin and Nanofibers & Cutaneous & Anti-inflammatory & Bioactive \\
\hline [94] & 2013 & Stenachaenium megapotamicum $\mathrm{EO}$ & Nanoemulsion & Cutaneous & Antidermatophytic & Bioactive \\
\hline [95] & 2013 & Anethum graveolens $\mathrm{EO}$ & Liposomes & Cutaneous & Antifungal & Bioactive \\
\hline [96] & 2013 & M. alternifolia $\mathrm{EO}$ & Nanoemulsion and nanocapsules & Ungueal & Onychomycosis treatment & Bioactive \\
\hline [97] & 2012 & C. multijuga $\mathrm{EO}$ & Nanoemulsion & Percutaneous & Anti-inflammatory & Bioactive \\
\hline [98] & 2012 & Turmeric oil & Nanoemulsion & Cutaneous & Psoriasis treatment & Bioactive \\
\hline [99] & 2009 & Citronella oil & Nanoemulsion & Cutaneous & Repellent & Bioactive \\
\hline [100] & 2007 & Artemisia arborescens $\mathrm{EO}$ & Solid Lipid Nanoparticles & Cutaneous & Antiviral & Bioactive \\
\hline [101] & 2004 & Viton oil & Liposomes & Cutaneous & Anti-inflammatory & Bioactive \\
\hline
\end{tabular}




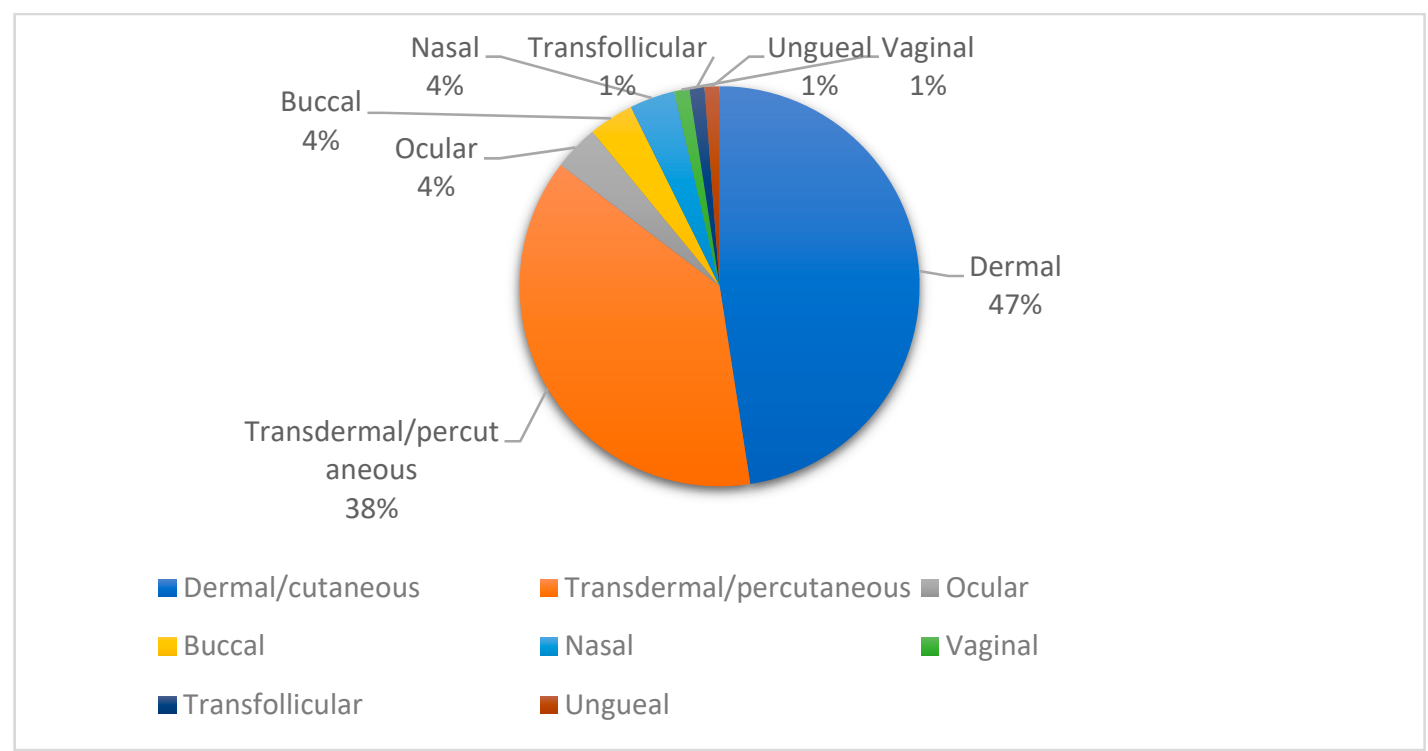

Figure 3. Topical administration routes of nanoencapsulated essential oils (EO) containing terpenes and isolated terpenes.

\subsection{Role of Essential Oil and/or Terpenes in the Formulations}

In order to understand the applications of EO containing terpenes and/or isolated terpenes encapsulated in nanosystems intended for topical administration, the studies were divided between those in which EO/terpenes were used as excipient and those in which they were used as bioactive compounds. Of 82 studies, 56 employed terpenes/EO as bioactive ingredients in formulations, whereas 29 reported terpenes/EO as excipients in formulations (Figure 4). Zhang et al. [38] reported both bioactive (anti-inflammatory) and penetration-enhancing activities of the terpene Paeoniflorin encapsulated in glycerosomes. Also, Castangia et al. [90] described the preparation of permeation-enhancing vehicles containing Santolina insularis EO as an antimicrobial and permeation enhancer for percutaneous drug delivery.

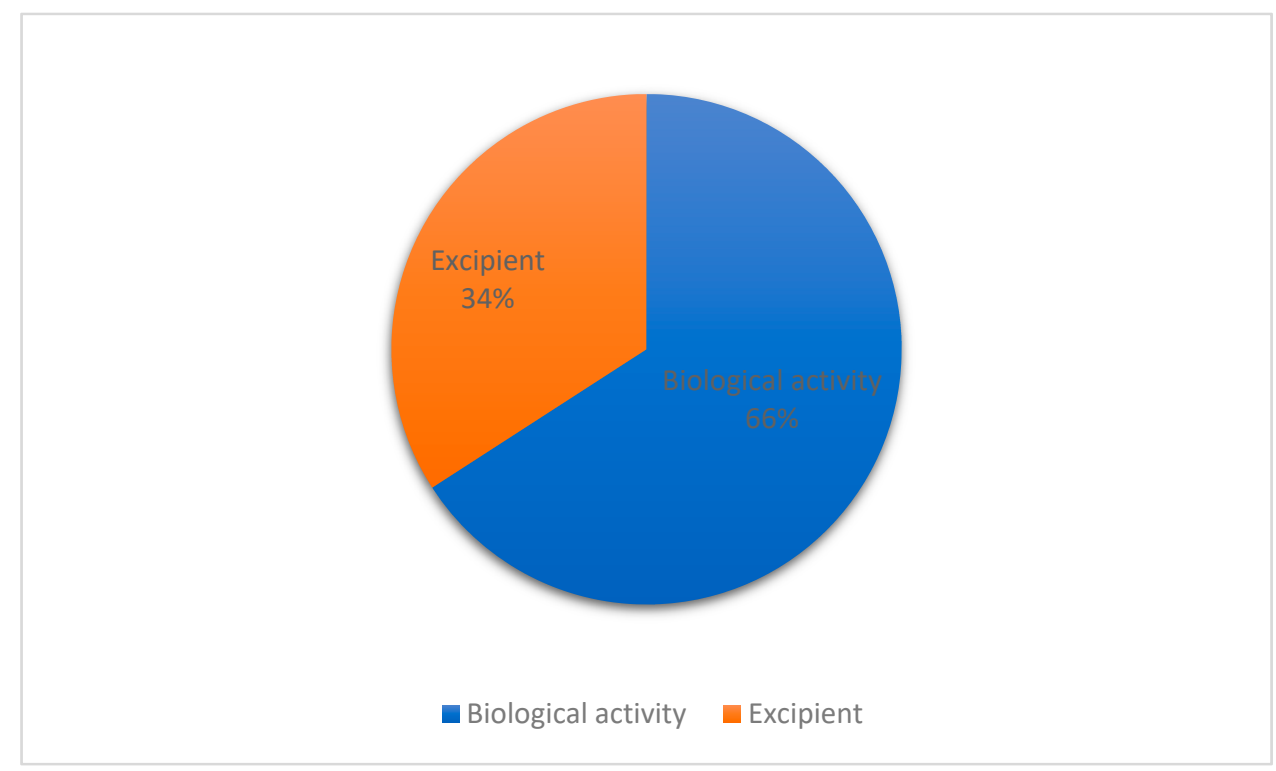

Figure 4. Application of $\mathrm{EO} /$ terpenes as excipients or bioactive ingredients in formulations. 
Many biological and pharmacological activities of EO and terpenes are well described in the literature, and the interest in their use as bioactive ingredients in pharmaceutical formulations has been rising recently, alongside with the seek for natural products as alternatives for drug development $[1,5]$.

In general, the use of terpenes as excipients aims to increase the permeation of the active compound through skin layers, since terpenes are extensively cited in the literature as permeation enhancers $[7,15,102]$. The application of terpenes as excipients is further discussed in Section 3.2.2.

3.2.1. Nanostructured Systems Used in the Encapsulation of Terpenes and Essential Oils as Bioactive Ingredients

The therapeutic potential of terpenes and EO containing terpenes is well known. Biological activities such as bactericidal, fungicidal, antioxidant, virucidal, and antineoplastic activities are well recognized [3,5,103]. There is a number of good reviews in the literature that list the variety of nanostructured systems and preparation techniques employed in the encapsulation of EO in nanostructures systems $[1,2,104]$, but none focused on terpenes. Among the studies listed in Tables 1 and 2, the most widely investigated biological activities upon nanoencapsulation of essential oils and isolated terpenes were the anti-inflammatory activity of essential oils and oil resins containing terpenes, such as plai oil [93], Copaifera multijuga oil [89,97], Nigella sativa EO [78], and of the isolated terpenes triptolide [41,65,71,73], sericoside [72], thymol [10] and oleanoic and ursolic acids [53], as well as the wound healing properties of Syzygium aromaticum EO [83], Melaleuca alternifolia EO [91], triterpenes from Centella asiatica extract [85], madecassoside [105], asiaticoside [48], astragaloside IV [59], and hyperforin [11]. Also, the nanoencapsulation of the well-established taxane antineoplastic drugs paclitaxel [14] and docetaxel [13,35] were studied for topical administration.

The systems can be divided according to their composition of polymers and lipids [21]. Polymer-based systems can be constituted by natural, synthetic, and semisynthetic polymers and comprise systems such as nanocapsules (NC), nanoparticles (NP), nanofibers (NF), and nanogels (NG). On the other hand, the lipid-based systems, namely, nanoemulsions (NE), liposomes (LS), solid lipid nanoparticles (SLN), nanostructured lipid carriers (NLC), and vesicular systems (VS) which comprehend ethosomes, phytosomes, niosomes, glycerosomes, and invasomes (IV) [106], are formed by lipids [104]. In addition, molecular complexation of terpenes with cyclodextrins is reported in the literature as a strategy for essential oil and natural products nanoencapsulation [2,107].

Encapsulation in nanometric systems is widely described in the literature as an approach to overcome many disadvantages concerning essential oils by providing protection against environmental factors that can cause chemical degradation and avoiding volatilization of EO components. In addition, nanoencapsulation can improve the bioavailability, allow controlled drug release, and enable the passage of the bioactive compounds through biological barriers [21]. Patel et al. [62] compared the cutaneous permeation of the sesquiterpene Hurpezine A from transdermal gels after encapsulation in three different systems, i.e., microemulsion (ME), SLN, and NLC, and the in vivo activity in an experimental mice model of induced amnesia. The ME formulation presented the highest cumulative permeated amounts, followed by NLC and SLN. The in vivo experiments presented no significant difference between the three formulations, but positive outcomes when compared to the negative control. In other study of comparison between different nanostructured systems, Flores et al. [96] investigated nanocapsule suspensions and nanoemulsions containing tea tree oil against in in vitro onychomycosis models. Although both nanometric systems presented better antifungal activity compared to the coarse emulsion containing tea tree oil, the nanocapsule formulation was more effective against the microorganism. This may be attributed to the polymer barrier that prevents the volatilization of bioactive compounds as well as the capacity of the aqueous suspension to hydrate the tissue and therefore enhance the penetration of nanostructures.

Also, the complexation with cyclodextrins can be an interesting alternative, since it is reported to provide protection against environmental factors, improve stability, avoid volatilization of EO components, improve oral bioavailability, and reduce mucosal irritation [23]. In addition, cyclodextrins 
are described as safe options to enhance the permeation of molecules through the skin and mucosae $[2,15,108]$. The complexation of essential oils and isolated terpenes with cyclodextrins has been reported in the literature and reviewed [23,109,110]; however, the majority of investigations concerning complexes between cyclodextrins and essential oils or isolated terpenes for pharmaceutical applications are limited to oral administration, with few studies focusing on topical administration, and no reviews found in the literature covering this subject specifically. Rode et al. [72] studied the influence of cyclodextrin complexation on the percutaneous penetration in pig skin of the triterpenoid sericoside from a Terminalia sericea extract. The formulation containing the sericoside from the extract complexed with $\gamma$-cyclodextrin increased the percutaneous penetration 2.6 times when compared to an ethanolic solution of sericoside.

As illustrated in Figure 5, a variety of different nanostructured systems are used in the encapsulation of EO and terpenes. It can be noticed that lipid-based nanosystems are used in $67 \%$ of the formulations reported, which may be attributed to their low toxicity.

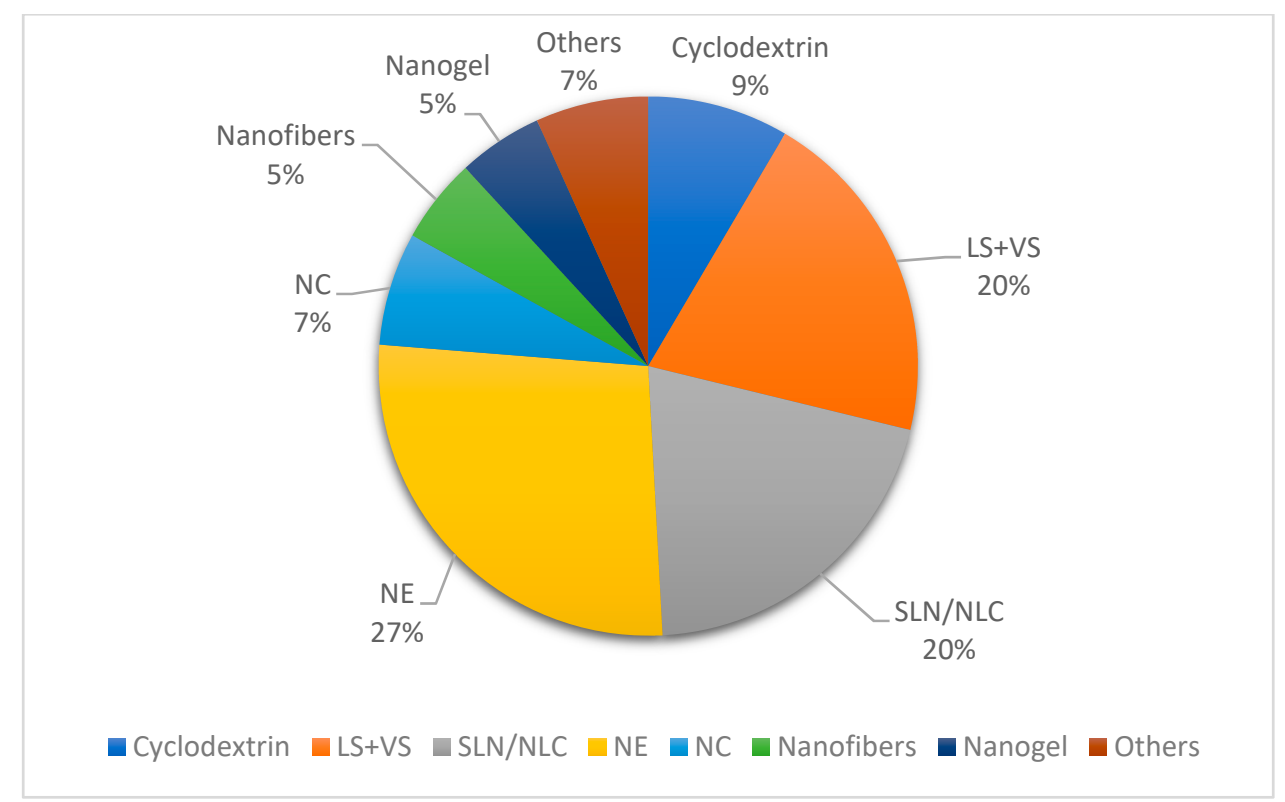

Figure 5. Nanostructured systems used in the encapsulation of essential oils containing terpenes and isolated terpenes as bioactive compounds for topical formulations. LS, liposomes, VS, vesicular systems, SLN, solid lipid nanoparticles, NLC, nanostructured lipid carriers, NE, nanoemulsions, NC, nanocapsules.

Although various preparation techniques of nanostructured systems are extensively described in the literature $[1,2,104]$, it is important to pay attention to the preparation technique in terms on its influence on $\mathrm{EO} /$ terpene stability, because of their sensitivity to heat and pressure. In this context, the quantification of chemical markers of EO or terpenes is essential, especially in cases where they play a role as bioactive compounds, in order to ensure the integrity of $\mathrm{EO} /$ terpene content in the final formulation and, thus, the safety and efficacy of the final product [104].

\subsubsection{Terpenes as Excipients in Formulations for Topical Administration}

Transdermal drug delivery represents a convenient route of administration for systemic action due to its non-invasive characteristic [102,111]. However, it is limited by the ability of the drug to permeate through the skin layers, especially the stratum corneum (SC). The use of penetration enhancers is a promising strategy to broaden the range of drugs eligible for transdermal delivery [112].

Permeation enhancers are used as excipients in formulations and are capable of facilitating the passage of a drug through the skin. Besides their biological activities, essential oils and isolated terpenes have been described as promising permeation enhancers for transdermal drug delivery. They 
can enhance the passage of drugs through the skin by interacting with stratum corneum lipids and modifying the solubility characteristics of these lipids, facilitating drug partitioning towards deeper layers of the skin $[7,8,15,102]$. Furthermore, terpenes are considered safer than other permeation enhancers from a toxicological point of view, with some terpenes being included in the list of Generally Recognized as Safe (GRAS) compounds from the US FDA (United States Food and Drug Administration) [8].

The nanostructured systems in which terpenes are used as excipients are illustrated in Figure 6. The majority of systems are based on vesicular structures (LS, I,V and permeation-enhancing vehicles (PEV)), with the invasomes representing $27 \%$ of the nanostructured systems reported, followed by liposomes and nanoemulsions (20\%).

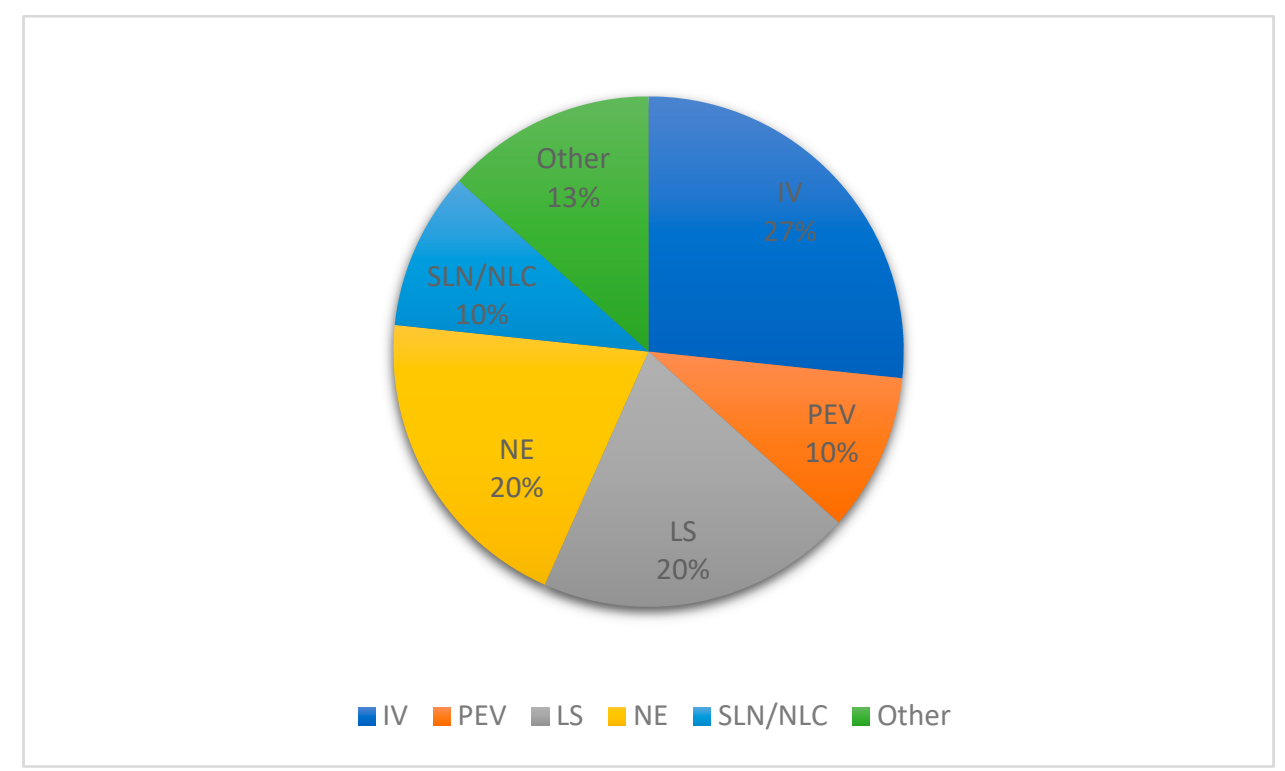

Figure 6. Nanostructured systems used in formulations containing essential oils and/or isolated terpenes excipients for topical administration. IV: invasomes, PEV: permeation-enhancing vehicles.

Invasomes (also found in the literature as invasosomes) are special drug delivery systems that contain terpenes and are the most recurrent among the formulations of nanosystems using terpenes as excipients (Figure 6). They are, by definition, vesicular systems consisting of terpenes, ethanol, and phospholipids as fundamental raw materials and present elasticity and deformability, which favors penetration across skin layers, and thus they work as penetration-enhancing vehicles [113]. According to the data presented in Tables 1 and 2, the terpenes used in the formulation of invasomes are limonene, cineole, fenchone, citral, and beta-citronellene; all of them are monoterpenes or monoterpenoids (Figure 7).<smiles>C=C(C)[C@H]1CC=C(C)CC1</smiles>

Limonene

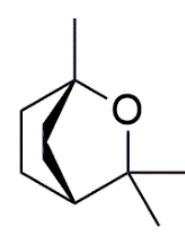

Cineole

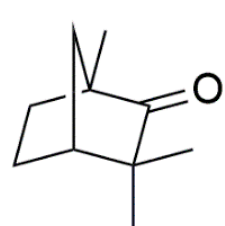

Fenchone<smiles>CC(C)=CCC/C(C)=C/C=O</smiles>

Citral<smiles>C=C[C@H](C)CCC=C(C)C</smiles>

Beta-Citronellene

Figure 7. Monoterpenes used as permeation enhancers in nanostructured systems. 
Kamran et al. [45] studied the preparation of invasomes using beta-citronellene as a permeation enhancer for transdermal delivery of the antihypertensive olmesartan and observed an increase in the bioavailability of olmesartan from invasomes in Wistar rats compared to the control. Incorporation of isradipine, also an antihypertensive agent, in invasomes containing beta-citronellene was investigated by Qadri et al. [42], who showed a decrease of $20 \%$ of blood pressure in rats. The permeation of rhodamine B invasomes through rat skin was evaluated by confocal laser spectroscopy, and fluorescence was detected at a depth of $171.18 \mathrm{~mm}$ in the skin. A series of studies focused on the encapsulation of temoporfin in invasomes, aiming to improve its penetration through the skin using several different proportions of cineole, citral, and d-limonene. The findings indicated that the optimal amount of terpenes in formulations should be $1 \%(\mathrm{v} / \mathrm{v})$, and the formulation containing $1 \%$ of cineole alone led to higher permeation of the drug to deeper layers of the skin compared to mixtures of the three terpenes in varied proportions and limonene and citral alone [68-70]. El-Nabarawi et al. [25] prepared dapsone-loaded invasomes for acne treatment, containing different terpenes (limonene, cineole, citral, or fenchone) in varied concentrations in a full factorial design study and compared drug deposition in vivo of optimized formulations with dapsone solution, finding a 2.5-fold increase in dapsone deposition with the invasomes formulation.

\subsection{Safety of Essential Oils and Terpenes in Topical Administration}

One important concern is the safety of the use of essential oils and terpenes in topical formulations. Although a number of essential oils and terpenes are considered GRAS [8], few studies investigated the safety of these compounds in topical application. Lalko and Api [114] investigated the skin irritancy of essential oils and their isolated compounds, concluding that, in many cases, there is a potential induction of sensibilization upon exposure to these compounds. Some terpenes, as described in previous sections of this review, are used as permeation enhancers in drug delivery systems. They are considered non-toxic, nonirritant, and, therefore, a safe option for permeation enhancement [115].

\subsection{Sustainability}

In recent decades, the efforts to reduce the environmental impact of chemical compounds and develop green chemistry have been growing. Terpenes and essential oils comprise a renewable source of chemical compounds and have been already described in the literature as "greener" alternatives to pesticides [116] and solvents [117]. Concerning the preparation of nanostructured systems, essential oils and terpenes can be used as more sustainable additives, being able to substitute organic solvents in the preparation of nanocapsules [118] and in the synthesis of metallic nanoparticles [119]. Also, effort has been made for the development of essential oil extraction techniques with no or less solvent and energy use without quality loss [120]. When observing the 12 principles of Green Chemistry [121], it is possible to see that the use of terpenes and essential oils may have some positive effects, since, as aforementioned, they are renewable supplies and present low toxicity [8]. Furthermore, in the development of new formulations containing essential oils and terpenes, the 12 principles (prevention, atom economy, less hazardous chemical synthesis, designing safer chemicals, safer solvents and auxiliaries, design for energy efficient, use of renewable feedstocks, reduce derivatives, catalysis, design for degradation, real-time analysis for pollution prevention, and inherently safer chemistry for accident prevention) should be respected, since, besides reducing the environmental impact of chemicals, they can also lead to lower costs of production [122], which can balance out investments made in the development and implementation of sustainable alternatives.

\section{Concluding Remarks}

The interest in the development of nanostructured systems containing essential oils and terpenes designed for topical administration routes has been rising in recent years. The majority of the formulations employ EO and/or terpenes as active ingredients encapsulated in nanostructured systems as means to improve the physicochemical properties and/or achieve greater bioavailability and 
controlled release of drugs. On the other hand, a part of the studies also shows the growing interest in using terpenes as permeation-enhancer excipients in transdermal delivery systems, a promising strategy for efficient and noninvasive drug delivery to the skin deeper layers.

Terpenes and essential oils present a sustainable alternative as raw materials in the pharmaceutical field and thus a valuable source, giving the growing importance of "greener" chemistry. Many of them are considered GRAS; however, there is a lack of information concerning their safety in topical administration.

Supplementary Materials: The following are available online at http://www.mdpi.com/2218-273X/9/4/138/s1, Table S1: Database search lines.

Author Contributions: Conceptualization-all authors; Data curation-S.P.d.M.; Formal analysis-S.P.d.M. and L.S.K.; Methodology-S.P.d.M. and L.S.K.; Supervision—L.S.K.; Writing—original draft-S.P.d.M. and L.S.K.; Writing — review \& editing—all authors.

Funding: This study was financed in part by the "Coordenação de Aperfeiçoamento de Pessoal de Nível Superior-Brasil" (CAPES). Finance Code 001.

Acknowledgments: The authors thank CAPES and CNPq for their scholarships.

Conflicts of Interest: The authors declare no conflict of interest.

\section{References}

1. Asbahani, A.E.; Miladi, K.; Badri, W.; Sala, M.; Addi, E.H.A.; Casabianca, H.; Mousadik, A.E.; Hartmann, D.; Jilale, A.; Renaud, F.N.R.; et al. Essential oils: From extraction to encapsulation. Int. J. Pharm. 2015, 483, 220-243. [CrossRef] [PubMed]

2. Bilia, A.R.; Guccione, C.; Isacchi, B.; Righeschi, C.; Firenzuoli, F.; Bergonzi, M.C. Essential oils loaded in nanosystems: A developing strategy for a successful therapeutic approach. Evid. Based Complement. Alternat. Med. 2014, 2014. [CrossRef] [PubMed]

3. Majeed, H.; Bian, Y.-Y.; Ali, B.; Jamil, A.; Majeed, U.; Khan, Q.F.; Iqbal, K.J.; Shoemaker, C.F.; Fang, Z. Essential oil encapsulations: Uses, procedures, and trends. RSC Adv. 2015, 5, 58449-58463. [CrossRef]

4. Gershenzon, J.; Dudareva, N. The function of terpene natural products in the natural world. Nat. Chem. Biol. 2007, 3, 408. [CrossRef] [PubMed]

5. Maffei, M.E.; Gertsch, J; Appendino, G. Plant volatiles: Production, function and pharmacology. Nat. Prod. Rep. 2011, 28, 1359-1380. [CrossRef] [PubMed]

6. Turek, C.; Stintzing, F.C. Stability of Essential Oils: A Review. Compr. Rev. Food Sci. F 2013, 12, 40-53. [CrossRef]

7. Herman, A.; Herman, A.P. Essential oils and their constituents as skin penetration enhancer for transdermal drug delivery: A review. J. Pharm. Pharmacol. 2014, 67, 473-485. [CrossRef]

8. Sapra, B.; Jain, S.; Tiwary, A.K. Percutaneous Permeation Enhancement by Terpenes: Mechanistic View. AAPS J. 2008, 10, 120. [CrossRef]

9. Hamm, S.; Bleton, J.; Connan, J.; Tchapla, A. A chemical investigation by headspace SPME and GC-MS of volatile and semi-volatile terpenes in various Olibanum samples. Phytochemistry 2005, 66, 1499-1514. [CrossRef]

10. Pivetta, T.P.; Simões, S.; Araújo, M.M.; Carvalho, T.; Arruda, C.; Marcato, P.D. Development of nanoparticles from natural lipids for topical delivery of thymol: Investigation of its anti-inflammatory properties. Colloids Surf. B Biointerfaces 2018, 164, 281-290. [CrossRef]

11. Takada, H.; Yonekawa, J.; Matsumoto, M.; Furuya, K.; Sokabe, M. Hyperforin/HP- $\beta$-Cyclodextrin Enhances Mechanosensitive $\mathrm{Ca}^{2+}$ Signaling in HaCaT Keratinocytes and in Atopic Skin Ex Vivo Which Accelerates Wound Healing. Biomed. Res. Int. 2017, 2017, 8701801. [CrossRef]

12. Tosta, F.V.; Andrade, L.M.; Mendes, L.P.; Anjos, J.L.V.; Alonso, A.; Marreto, R.N.; Lima, E.M.; Taveira, S.F. Paclitaxel-loaded lipid nanoparticles for topical application: The influence of oil content on lipid dynamic behavior, stability, and drug skin penetration. J. Nanopart. Res. 2014, 16, 1-12. [CrossRef]

13. Singh, H.; Sharma, R.; Joshi, M.; Garg, T.; Goyal, A.K.; Rath, G. Transmucosal delivery of Docetaxel by mucoadhesive polymeric nanofibers. Artif. Cells Nanomed. Biotechnol. 2015, 43, 263-269. [CrossRef] 
14. Bharadwaj, R.; Das, P.J.; Pal, P.; Mazumder, B. Topical delivery of paclitaxel for treatment of skin cancer. Drug Dev. Ind. Pharm. 2016, 42, 1482-1494. [CrossRef]

15. Sinha, V.R.; Kaur, M.P. Permeation Enhancers for Transdermal Drug Delivery. Drug Dev. Ind. Pharm. 2000, 26, 1131-1140. [CrossRef]

16. Scott, R.P.W. ESSENTIAL OILS. In Encyclopedia of Analytical Science, 2nd ed.; Worsfold, P., Townshend, A., Poole, C., Eds.; Elsevier: Oxford, UK, 2005; pp. 554-561.

17. Bhowmik, D.; Gopinath, H.; Kumar, B.P.; Duraivel, S.; Kumar, K.S. Recent advances in novel topical drug delivery system. Pharma Innov. 2012, 1, 12.

18. Brown, M.B.; Martin, G.P.; Jones, S.A.; Akomeah, F.K. Dermal and Transdermal Drug Delivery Systems: Current and Future Prospects. Drug Deliv. 2006, 13, 175-187. [CrossRef]

19. Guilherme, V.A.; Ribeiro, L.N.M.; Tofoli, G.R.; Franz-Montan, M.; de Paula, E.; de Jesus, M.B. Current challenges and future of lipid nanoparticles formulations for topical drug application to oral mucosa, skin, and eye. Curr. Pharm. Des. 2017, 23, 6659-6675. [CrossRef]

20. Sezer, A.D.; Cevher, E. Topical drug delivery using chitosan nano- and microparticles. Expert Opin. Drug Deliv. 2012, 9, 1129-1146. [CrossRef]

21. Bilia, A.R.; Piazzini, V.; Guccione, C.; Risaliti, L.; Asprea, M.; Capecchi, G.; Bergonzi, M.C. Improving on Nature: The Role of Nanomedicine in the Development of Clinical Natural Drugs. Planta Med. 2017, 83, 366-381. [CrossRef]

22. Barua, S.; Mitragotri, S. Challenges associated with penetration of nanoparticles across cell and tissue barriers: A review of current status and future prospects. Nano Today 2014, 9, 223-243. [CrossRef]

23. Lima, P.S.S.; Lucchese, A.M.; Araújo-Filho, H.G.; Menezes, P.P.; Araújo, A.A.S.; Quintans-Júnior, L.J.; Quintans, J.S.S. Inclusion of terpenes in cyclodextrins: Preparation, characterization and pharmacological approaches. Carbohydr. Polym. 2016, 151, 965-987. [CrossRef]

24. Saettone, M.F.; Burgalassi, S.; Giannaccini, B. Preparation and Evaluation in Rabbits of Topical Solutions Containing Forskolin. J. Ocul. Pharmacol. Ther. 1989, 5, 111-118. [CrossRef]

25. El-Nabarawi, M.A.; Shamma, R.N.; Farouk, F.; Nasralla, S.M. Dapsone-Loaded Invasomes as a Potential Treatment of Acne: Preparation, Characterization, and In Vivo Skin Deposition Assay. AAPS PharmSciTech 2018, 19, 2174-2184. [CrossRef]

26. Ahmad, A.; Abuzinadah, M.F.; Alkreathy, H.M.; Banaganapalli, B.; Mujeeb, M. Ursolic acid rich ocimum sanctum $L$ leaf extract loaded nanostructured lipid carriers ameliorate adjuvant induced arthritis in rats by inhibition of COX-1, COX-2, TNF- $\alpha$ and IL-1: Pharmacological and docking studies. PLoS ONE 2018, 13, e0193451. [CrossRef]

27. Abdel-Hafez, S.M.; Hathout, R.M.; Sammour, O.A. Curcumin-loaded ultradeformable nanovesicles as a potential delivery system for breast cancer therapy. Colloids Surf. B Biointerfaces 2018, 167, 63-72. [CrossRef]

28. Cui, Y.; Mo, Y.; Zhang, Q.; Tian, W.; Xue, Y.; Bai, J.; Du, S. Microneedle-Assisted Percutaneous Delivery of Paeoniflorin-Loaded Ethosomes. Molecules 2018, 23, 3371. [CrossRef]

29. Song, K.; Xin, M.; Yu, H.; Zheng, Z.; Li, J.; Li, M.; Guo, H.; Tan, Y.; Wu, X. Novel ultra-small micelles based on rebaudioside A: A potential nanoplatform for ocular drug delivery. Int. J. Pharm. 2018, 552, 265-276. [CrossRef]

30. Sims, K.R.; Liu, Y.; Hwang, G.; Jung, H.I.; Koo, H.; Benoit, D.S.W. Enhanced design and formulation of nanoparticles for anti-biofilm drug delivery. Nanoscale 2019, 11, 219-236. [CrossRef]

31. Abd, E.; Benson, H.A.E.; Roberts, M.S.; Grice, J.E. Follicular Penetration of Caffeine from Topically Applied Nanoemulsion Formulations Containing Penetration Enhancers: In vitro Human Skin Studies. Skin Pharmacol. Physiol. 2018, 31, 252-260. [CrossRef]

32. Nagai, N.; Ogata, F.; Otake, H.; Nakazawa, Y.; Kawasaki, N. Design of a transdermal formulation containing raloxifene nanoparticles for osteoporosis treatment. Int. J. Nanomed. 2018, 13, 5215-5229. [CrossRef]

33. Freag, M.S.; Saleh, W.M.; Abdallah, O.Y. Laminated chitosan-based composite sponges for transmucosal delivery of novel protamine-decorated tripterine phytosomes: Ex-vivo mucopenetration and in-vivo pharmacokinetic assessments. Carbohydr. Polym. 2018, 188, 108-120. [CrossRef]

34. Khan, K.; Aqil, M.; Imam, S.S.; Ahad, A.; Moolakkadath, T.; Sultana, Y.; Mujeeb, M. Ursolic acid loaded intra nasal nano lipid vesicles for brain tumour: Formulation, optimization, in-vivo brain/plasma distribution study and histopathological assessment. Biomed. Pharmacother. 2018, 106, 1578-1585. [CrossRef] 
35. Bonaccorso, A.; Musumeci, T.; Carbone, C.; Vicari, L.; Lauro, M.R.; Puglisi, G. Revisiting the role of sucrose in PLGA-PEG nanocarrier for potential intranasal delivery. Pharm. Dev. Technol. 2018, 23, 265-274. [CrossRef]

36. Lason, E.; Sikora, E.; Miastkowska, M.; Escribano, E.; Garcia-Celma, M.J.; Solans, C.; Llinas, M.; Ogonowski, J. NLCs as a potential carrier system for transdermal delivery of forskolin. Acta Biochim. Pol. 2018, 65, 437-442. [CrossRef]

37. Wang, J.; Wei, Y.; Fei, Y.R.; Fang, L.; Zheng, H.S.; Mu, C.F.; Li, F.Z.; Zhang, Y.S. Preparation of mixed monoterpenes edge activated PEGylated transfersomes to improve the in vivo transdermal delivery efficiency of sinomenine hydrochloride. Int. J. Pharm. 2017, 533, 266-274. [CrossRef]

38. Zhang, K.; Zhang, Y.; Li, Z.; Li, N.; Feng, N. Essential oil-mediated glycerosomes increase transdermal paeoniflorin delivery: Optimization, characterization, and evaluation in vitro and in vivo. Int. J. Nanomed. 2017, 12, 3521-3532. [CrossRef]

39. Duangit, S.; Nimcharoenwan, T.; Chomya, N.; Locharoenrat, N.; Ngawhirunpat, T. Computational design strategy: An approach to enhancing the transdermal delivery of optimal capsaicin-loaded transinvasomes. Drug Dev. Ind. Pharm. 2017, 43, 98-107. [CrossRef]

40. Rangsimawong, W.; Obata, Y.; Opanasopit, P.; Ngawhirunpat, T.; Takayama, K. Enhancement of Galantamine HBr Skin Permeation Using Sonophoresis and Limonene-Containing PEGylated Liposomes. AAPS PharmSciTech 2017, 19, 1093-1104. [CrossRef]

41. Yang, M.; Gu, Y.; Yang, D.; Tang, X.; Liu, J. Development of triptolide-nanoemulsion gels for percutaneous administration: Physicochemical, transport, pharmacokinetic and pharmacodynamic characteristics. J. Nanobiotechnol. 2017, 15, 88. [CrossRef]

42. Qadri, G.R.; Ahad, A.; Aqil, M.; Imam, S.S.; Ali, A. Invasomes of isradipine for enhanced transdermal delivery against hypertension: Formulation, characterization, and in vivo pharmacodynamic study. Artif. Cells Nanomed. Biotechnol. 2017, 45, 139-145. [CrossRef]

43. Teixeira, G.F.D.; Vieira-Neto, A.E.; da Costa, F.N.; e Silva, A.R.A.; Campos, A.R. Antinociceptive effect of (-)- $\alpha$-bisabolol in nanocapsules. Biomed. Pharmacother. 2017, 91, 946-950. [CrossRef]

44. Abdelsamie, S.M.; Kamel, A.O.; Sammour, O.A.; Ibrahim, S.M. Terbinafine hydrochloride nanovesicular gel: In vitro characterization, ex vivo permeation and clinical investigation. Eur. J. Pharm. Sci. 2016, 88, 91-100. [CrossRef]

45. Kamran, M.; Ahad, A.; Aqil, M.; Imam, S.S.; Sultana, Y.; Ali, A. Design, formulation and optimization of novel soft nano-carriers for transdermal olmesartan medoxomil delivery: In vitro characterization and in vivo pharmacokinetic assessment. Int. J. Pharm. 2016, 505, 147-158. [CrossRef]

46. Gogoll, K.; Stein, P.; Lee, K.; Arnold, P.; Peters, T.; Schild, H.; Radsak, M.; Langguth, P. Solid nanoemulsion as antigen and immunopotentiator carrier for transcutaneous immunization. Cell. Immunol. 2016, 308, $35-43$. [CrossRef]

47. Li, M.; Zhu, L.; Liu, B.; Du, L.; Jia, X.; Han, L.; Jin, Y. Tea tree oil nanoemulsions for inhalation therapies of bacterial and fungal pneumonia. Colloids Surf. B Biointerfaces 2016, 141, 408-416. [CrossRef]

48. Zhu, L.; Liu, X.; Du, L.; Jin, Y. Preparation of asiaticoside-loaded coaxially electrospinning nanofibers and their effect on deep partial-thickness burn injury. Biomed. Pharmacother. 2016, 83, 33-40. [CrossRef]

49. Shen, C.Y.; Xu, P.H.; Shen, B.D.; Min, H.Y.; Li, X.R.; Han, J.; Yuan, H.L. Nanogel for dermal application of the triterpenoids isolated from Ganoderma lucidum (GLT) for frostbite treatment. Drug Deliv. 2016, 23, 610-618. [CrossRef]

50. Ahmad, M.; Rai, S.M.; Mahmood, A. Hydrogel Microparticles as an Emerging Tool in Pharmaceutical Field: A Review. Adv. Polym. Technol. 2016, 35, 121-128. [CrossRef]

51. Jamal, M.; Imam, S.S.; Aqil, M.; Amir, M.; Mir, S.R.; Mujeeb, M. Transdermal potential and anti-arthritic efficacy of ursolic acid from niosomal gel systems. Int. Immunopharmacol. 2015, 29, 361-369. [CrossRef]

52. Horev, B.; Klein, M.I.; Hwang, G.; Li, Y.; Kim, D.; Koo, H.; Benoit, D.S.W. pH-activated Nanoparticles for Controlled Topical Delivery of Farnesol to Disrupt Oral Biofilm Virulence. ACS Nano 2015, 9, 2390-2404. [CrossRef]

53. Alvarado, H.; Abrego, G.; Souto, E.B.; Garduño-Ramirez, M.L.; Clarés, B.; García, M.; Calpena, A. Nanoemulsions for dermal controlled release of oleanolic and ursolic acids: In vitro, ex vivo and in vivo characterization. Colloids Surf. B Biointerfaces 2015, 130, 40-47. [CrossRef] [PubMed]

54. Lu, W.-C.; Chiang, B.-H.; Huang, D.-W.; Li, P.-H. Skin permeation of d-limonene-based nanoemulsions as a transdermal carrier prepared by ultrasonic emulsification. Ultrason. Sonochem. 2014, 21, 826-832. [CrossRef] 
55. Rangsimawong, W.; Opanasopit, P.; Rojanarata, T.; Ngawhirunpat, T. Terpene-Containing PEGylated Liposomes as Transdermal Carriers of a Hydrophilic Compound. Boil. Pharm. Bull. 2014, 37, 1936-1943. [CrossRef]

56. Charoenputtakun, P.; Pamornpathomkul, B.; Opanasopit, P.; Rojanarata, T.; Ngawhirunpat, T. Terpene Composited Lipid Nanoparticles for Enhanced Dermal Delivery of All-trans-Retinoic Acids. Boil. Pharm. Bull. 2014, 37, 1139-1148. [CrossRef]

57. Dehelean, C.A.; Feflea, S.; Gheorgheosu, D.; Ganta, S.; Cimpean, A.M.; Muntean, D.; Amiji, M.M. Anti-Angiogenic and Anti-Cancer Evaluation of Betulin Nanoemulsion in Chicken Chorioallantoic Membrane and Skin Carcinoma in Balb/c Mice. J. Biomed. Nanotechnol. 2013, 9, 577-589. [CrossRef]

58. Sandig, A.G.; Campmany, A.C.; Campos, F.F.; Villena, M.M.; Naveros, B.C. Transdermal delivery of imipramine and doxepin from newly oil-in-water nanoemulsions for an analgesic and anti-allodynic activity: Development, characterization and in vivo evaluation. Colloids Surf. B Biointerfaces 2013, 103, 558-565. [CrossRef]

59. Chen, X.; Peng, L.-H.; Shan, Y.-H.; Li, N.; Wei, W.; Yu, L.; Li, Q.-M.; Liang, W.-Q.; Gao, J.-Q. Astragaloside IV-loaded nanoparticle-enriched hydrogel induces wound healing and anti-scar activity through topical delivery. Int. J. Pharm. 2013, 447, 171-181. [CrossRef]

60. Subongkot, T.; Wonglertnirant, N.; Songprakhon, P.; Rojanarata, T.; Opanasopit, P.; Ngawhirunpat, T. Visualization of ultradeformable liposomes penetration pathways and their skin interaction by confocal laser scanning microscopy. Int. J. Pharm. 2013, 441, 151-161. [CrossRef]

61. Barros, N.B.; Migliaccio, V.; Facundo, V.A.; Ciancaglini, P.; Stabeli, R.G.; Nicolete, R.; Silva-Jardim, I. Liposomal-lupane system as alternative chemotherapy against cutaneous leishmaniasis: Macrophage as target cell. Exp. Parasitol. 2013, 135, 337-343. [CrossRef]

62. Patel, P.A.; Patil, S.C.; Kalaria, D.R.; Kalia, Y.N.; Patravale, V.B. Comparative in vitro and in vivo evaluation of lipid based nanocarriers of Huperzine A. Int. J. Pharm. 2013, 446, 16-23. [CrossRef]

63. Chen, Y.; Zhou, L.; Yuan, L.; Zhang, Z.-H.; Liu, X.; Wu, Q. Formulation, characterization, and evaluation of in vitro skin permeation and in vivo pharmacodynamics of surface-charged tripterine-loaded nanostructured lipid carriers. Int. J. Nanomed. 2012, 7, 3023-3033.

64. Paolino, D.; Cosco, D.; Cilurzo, F.; Trapasso, E.; Morittu, V.M.; Celia, C.; Fresta, M. Improved in vitro and in vivo collagen biosynthesis by asiaticoside-loaded ultradeformable vesicles. J. Control. 2012, 162, 143-151. [CrossRef] [PubMed]

65. Chen, J.-G.; Liu, Y.-F.; Gao, T.-W. Preparation and anti-inflammatory activity of triptolide ethosomes in an erythema model. J. Liposome Res. 2010, 20, 297-303. [CrossRef]

66. Fang, J.-Y. Combination of calcipotriol and methotrexate in nanostructured lipid carriers for topical delivery. Int. J. Nanomed. 2010, 5, 117. [CrossRef]

67. Mura, S.; Manconi, M.; Sinico, C.; Valenti, D.; Fadda, A.M. Penetration enhancer-containing vesicles (PEVs) as carriers for cutaneous delivery of minoxidil. Int. J. Pharm. 2009, 380, 72-79. [CrossRef]

68. Dragicevic-Curic, N.; Gräfe, S.; Albrecht, V.; Fahr, A. Topical application of temoporfin-loaded invasomes for photodynamic therapy of subcutaneously implanted tumours in mice: A pilot study. J. Photochem. Photobiol. B Boil. 2008, 91, 41-50. [CrossRef]

69. Dragicevic-Curic, N.; Scheglmann, D.; Albrecht, V.; Fahr, A. Temoporfin-loaded invasomes: Development, characterization and in vitro skin penetration studies. J. Control. 2008, 127, 59-69. [CrossRef]

70. Dragicevic-Curic, N.; Scheglmann, D.; Albrecht, V.; Fahr, A. Development of different temoporfin-loaded invasomes-Novel nanocarriers of temoporfin: Characterization, stability and in vitro skin penetration studies. Colloids Surf. B Biointerfaces 2009, 70, 198-206. [CrossRef]

71. Mei, Z.; Wu, Q.; Hu, S.; Lib, X.; Yang, X. Triptolide Loaded Solid Lipid Nanoparticle Hydrogel for Topical Application. Drug Dev. Ind. Pharm. 2005, 31, 161-168. [CrossRef]

72. Rode, T. Complex formation of sericoside with hydrophilic cyclodextrins: Improvement of solubility and skin penetration in topical emulsion-based formulations. Eur. J. Pharm. Biopharm. 2003, 55, 191-198. [CrossRef]

73. Mei, Z. Solid lipid nanoparticle and microemulsion for topical delivery of triptolide. Eur. J. Pharm. Biopharm. 2003, 56, 189-196. [CrossRef]

74. Afifah, S.N.; Azhar, S.; Ashari, S.E.; Salim, N. Development of a kojic monooleate-enriched oil-in-water nanoemulsion as a potential carrier for hyperpigmentation treatment. Int. J. Nanomed. 2018, 13, 6465-6479. 
75. Barradas, T.N.; Senna, J.P.; Cardoso, S.A.; Silva, K.G.D.E.; Mansur, C.R.E. Formulation characterization and in vitro drug release of hydrogel-thickened nanoemulsions for topical delivery of 8-methoxypsoralen. Mater. Sci. Eng. C Mater. Biol. Appl. 2018, 92, 245-253. [CrossRef] [PubMed]

76. Oliveira, C.A.; Gouvêa, M.M.; Antunes, G.R.; Freitas, Z.M.F.; Marques, F.F.C.; Ricci-Junior, E. Nanoemulsion containing 8-methoxypsoralen for topical treatment of dermatoses: Development, characterization and ex vivo permeation in porcine skin. Int. J. Pharm. 2018, 547, 1-9. [CrossRef] [PubMed]

77. Srivastava, N.; Patel, D.K.; Rai, V.K.; Pal, A.; Yadav, N.P. Development of Emulgel formulation for vaginal candidiasis: Pharmaceutical characterization, in vitro and in vivo evaluation. J. Drug Deliv. Sci. Technol. 2018, 48, 490-498. [CrossRef]

78. Alotaibi, F.O.; Mustafa, G.; Ahuja, A. Study of Enhanced Anti-Inflammatory Potential of Nigella Sativa in Topical Nanoformulation. Int. J. Pharm. Pharm. Sci. 2018, 10, 41. [CrossRef]

79. Barradas, T.N.; Senna, J.P.; Cardoso, S.A.; Nicoli, S.; Padula, C.; Santi, P.; Rossi, F.; Silva, K.G.D.E.; Mansur, C.R.E. Hydrogel-thickened nanoemulsions based on essential oils for topical delivery of psoralen: Permeation and stability studies. Eur. J. Pharm. Biopharm. 2017, 116, 38-50. [CrossRef]

80. Kalita, S.; Kandimalla, R.; Devi, B.; Kalita, B.; Kalita, K.; Deka, M.; Kataki, A.C.; Sharma, A.; Kotoky, J.

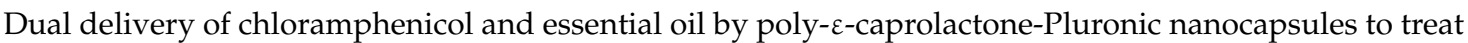
MRSA-Candida co-infected chronic burn wounds. RSC Adv. 2017, 7, 1749-1758. [CrossRef]

81. Montenegro, L.; Pasquinucci, L.; Zappalà, A.; Chiechio, S.; Turnaturi, R.; Parenti, C. Rosemary Essential Oil-Loaded Lipid Nanoparticles: In Vivo Topical Activity from Gel Vehicles. Pharmaceutics 2017, 9, 48. [CrossRef]

82. Navayan, A.; Moghimipour, E.; Khodayar, M.J.; Vazirianzadeh, B.; Siahpoosh, A.; Valizadeh, M.; Mansourzadeh, Z. Evaluation of the Mosquito Repellent Activity of Nano-sized Microemulsion of Eucalyptus globulus Essential Oil Against Culicinae. Jundishapur J. Nat. Pharm. Prod. 2017, 12. [CrossRef]

83. Alam, P.; Ansari, M.J.; Anwer, M.K.; Raish, M.; Kamal, Y.K.T.; Shakeel, F. Wound healing effects of nanoemulsion containing clove essential oil. Artif. Cells Nanomed. Biotechnol. 2017, 45, 591-597. [CrossRef] [PubMed]

84. Sinha, P.; Srivastava, S.; Mishra, N.; Singh, D.K.; Luqman, S.; Chanda, D.; Yadav, N.P. Development, optimization, and characterization of a novel tea tree oil nanogel using response surface methodology. Drug Dev. Ind. Pharm. 2016, 42, 1-12. [CrossRef] [PubMed]

85. Sawatdee, S.; Choochuay, K.; Chanthorn, W.; Srichana, T. Evaluation of the topical spray containing Centella asiatica extract and its efficacy on excision wounds in rats. Acta Pharm. 2016, 66, 233-244. [CrossRef]

86. Botelho, M.A.; Barros, G.; Queiroz, D.B.; Carvalho, C.F.; Gouvea, J.; Patrus, L.; Bannet, M.; Patrus, D.; Rego, A.; Silva, I.; et al. Nanotechnology in Phytotherapy: Antiinflammatory Effect of a Nanostructured Thymol Gel from Lippia sidoides in Acute Periodontitis in Rats. Phytother. Res. 2016, 30, 152-159. [CrossRef] [PubMed]

87. Mostafa, D.M.; El-Alim, S.H.A.; Asfour, M.H.; Al-Okbi, S.Y.; Mohamed, D.A.; Awad, G.; El-Alim, S.A. Transdermal nanoemulsions of Foeniculum vulgare Mill. essential oil: Preparation, characterization and evaluation of antidiabetic potential. J. Drug Deliv. Sci. Technol. 2015, 29, 99-106. [CrossRef]

88. Aldawsari, H.M.; Badr-Eldin, S.M.; Labib, G.S.; El-Kamel, A.H. Design and formulation of a topical hydrogel integrating lemongrass-loaded nanosponges with an enhanced antifungal effect: In vitro/in vivo evaluation. Int. J. Nanomed. 2015, 10, 893-902.

89. Lucca, L.G.; De Matos, S.P.; Borille, B.T.; Dias, D.D.O.; Teixeira, H.F.; Veiga, V.F.; Limberger, R.P.; Koester, L.S. Determination of $\beta$-caryophyllene skin permeation/retention from crude copaiba oil (Copaifera multijuga Hayne) and respective oil-based nanoemulsion using a novel HS-GC/MS method. J. Pharm. Biomed. Anal. 2015, 104, 144-148. [CrossRef]

90. Castangia, I.; Manca, M.L.; Caddeo, C.; Maxia, A.; Murgia, S.; Pons, R.; Demurtas, D.; Pando, D.; Falconieri, D.; Peris, J.E.; et al. Faceted phospholipid vesicles tailored for the delivery of Santolina insularis essential oil to the skin. Colloids Surf. B Biointerfaces 2015, 132, 185-193. [CrossRef]

91. Flores, F.C.; de Lima, J.A.; da Silva, C.R.; Benvegnú, D.; Ferreira, J.; Burger, M.E.; Beck, R.C.R.; Rolim, C.M.B.; Rocha, M.I.U.M.; da Veiga, M.L.; et al. Hydrogels Containing Nanocapsules and Nanoemulsions of Tea Tree Oil Provide Antiedematogenic Effect and Improved Skin Wound Healing. J. Nanosci. Nanotechnol. 2015, 15, 800-809. [CrossRef] 
92. Sugumar, S.; Ghosh, V.; Nirmala, M.J.; Mukherjee, A.; Chandrasekaran, N. Ultrasonic emulsification of eucalyptus oil nanoemulsion: Antibacterial activity against Staphylococcus aureus and wound healing activity in Wistar rats. Ultrason. Sonochem. 2014, 21, 1044-1049. [CrossRef] [PubMed]

93. Tonglairoum, P.; Chuchote, T.; Ngawhirunpat, T.; Rojanarata, T.; Opanasopit, P. Encapsulation of plai oil/2-hydroxypropyl- $\beta$-cyclodextrin inclusion complexes in polyvinylpyrrolidone (PVP) electrospun nanofibers for topical application. Pharm. Dev. Technol. 2014, 19, 430-437. [CrossRef] [PubMed]

94. Danielli, L.J.; Dos Reis, M.; Bianchini, M.; Camargo, G.S.; Bordignon, S.A.; Guerreiro, I.K.; Fuentefria, A.; Apel, M.A. Antidermatophytic activity of volatile oil and nanoemulsion of Stenachaenium megapotamicum (Spreng.) Baker. Ind. Crop. Prod. 2013, 50, 23-28. [CrossRef]

95. Ortan, A.; Ferdes, M.; Rodino, S.; Pirvu, C.D.; Draganescu, D. Liposomally encapsulated volatile oil of Anethum graveolens. Farmacia 2013, 61, 361-370.

96. Flores, F.C.; Lima, J.A.; Ribeiro, R.F.; Alves, S.H.; Rolim, C.M.B.; Beck, R.C.R.; Silva, C.B.; De Lima, J.A.; Da Silva, C.B. Antifungal Activity of Nanocapsule Suspensions Containing Tea Tree Oil on the Growth of Trichophyton rubrum. Mycopathologia 2013, 175, 281-286. [CrossRef] [PubMed]

97. Dias, D.D.O.; Colombo, M.; Kelmann, R.G.; De Souza, T.P.; Bassani, V.L.; Teixeira, H.F.; Veiga, V.F., Jr.; Limberger, R.P.; Koester, L.S. Optimization of headspace solid-phase microextraction for analysis of $\beta$-caryophyllene in a nanoemulsion dosage form prepared with copaiba (Copaifera multijuga Hayne) oil. Anal. Chim. 2012, 721, 79-84. [CrossRef] [PubMed]

98. Ali, M.S.; Alam, M.S.; Imam, F.I.; Siddiqui, M.R. Topical nanoemulsion of turmeric oil for psoriasis: Characterization, ex vivo and in vivo assessment. Int. J. Drug Deliv. 2012, 4. [CrossRef]

99. Sakulku, U.; Nuchuchua, O.; Uawongyart, N.; Puttipipatkhachorn, S.; Soottitantawat, A.; Ruktanonchai, U. Characterization and mosquito repellent activity of citronella oil nanoemulsion. Int. J. Pharm. 2009, 372, 105-111. [CrossRef]

100. Lai, F.; Sinico, C.; De Logu, A.; Zaru, M.; Müller, R.H.; Fadda, A.M. SLN as a topical delivery system for Artemisia arborescens essential oil: In vitro antiviral activity and skin permeation study. Int. J. Nanomed. 2007, 2, 419-425.

101. Suslina, S.N.; Alekseev, K.V.; Starodubova, M.V.; Bagirova, V.L. Drug synthesis methods and manufacturing technology: Development and comparative evaluation of a new liposomal dermatological preparation based on Viton oil. Pharm. Chem. J. 2004, 38, 492-497. [CrossRef]

102. Heather, A.E.B. Transdermal Drug Delivery: Penetration Enhancement Techniques. Curr. Drug Deliv. 2005, 2, 23-33.

103. Schnitzler, P.; Suschke, U.; Reichling, J.; Saller, R. Essential Oils of Aromatic Plants with Antibacterial, Antifungal, Antiviral, and Cytotoxic Properties-An Overview. Complement. Med. Res. 2009, 16, 79-90.

104. De Matos, S.P.; Lucca, L.G.; Koester, L.S. Essential oils in nanostructured systems: Challenges in preparation and analytical methods. Talanta 2019, 195, 204-214. [CrossRef] [PubMed]

105. Li, Z.; Liu, M.; Wang, H.; Du, S. Increased cutaneous wound healing effect of biodegradable liposomes containing madecassoside: Preparation optimization, in vitro dermal permeation, and in vivo bioevaluation. Int. J. Nanomed. 2016, 11, 2995-3007. [CrossRef] [PubMed]

106. Lohani, A.; Verma, A. Vesicles: Potential nano carriers for the delivery of skin cosmetics. J. Cosmet. Ther. 2017, 19, 485-493. [CrossRef] [PubMed]

107. Conte, R.; Marturano, V.; Peluso, G.; Calarco, A.; Cerruti, P.; Andrade, P.; Valentão, P. Recent Advances in Nanoparticle-Mediated Delivery of Anti-Inflammatory Phytocompounds. Int. J. Mol. Sci. 2017, 18, 709. [CrossRef]

108. Cal, K.; Centkowska, K. Use of cyclodextrins in topical formulations: Practical aspects. Eur. J. Pharm. Biopharm. 2008, 68, 467-478. [CrossRef]

109. Wadhwa, G.; Kumar, S.; Chhabra, L.; Mahant, S.; Rao, R. Essential oil-cyclodextrin complexes: An updated review. J. Incl. Phenom. Macrocycl. Chem. 2017, 89, 39-58. [CrossRef]

110. Marques, H.M.C. A review on cyclodextrin encapsulation of essential oils and volatiles. Flavour Fragr. J. 2010, 25, 313-326. [CrossRef]

111. Mura, S.; Manconi, M.; Fadda, A.M.; Sala, M.C.; Perricci, J.; Pini, E.; Sinico, C. Penetration enhancer-containing vesicles (PEVs) as carriers for cutaneous delivery of minoxidil: In vitro evaluation of drug permeation by infrared spectroscopy. Pharm. Dev. Technol. 2013, 18, 1339-1345. [CrossRef] 
112. Fox, L.T.; Gerber, M.; Du Plessis, J.; Hamman, J.H. Transdermal Drug Delivery Enhancement by Compounds of Natural Origin. Molecules 2011, 16, 10507-10540. [CrossRef]

113. Sinico, C.; Fadda, A.M. Vesicular carriers for dermal drug delivery. Opin. Drug Deliv. 2009, 6, 813-825. [CrossRef] [PubMed]

114. Lalko, J.; Api, A. Investigation of the dermal sensitization potential of various essential oils in the local lymph node assay. Chem. Toxicol. 2006, 44, 739-746. [CrossRef] [PubMed]

115. Aqil, M.; Ahad, A.; Sultana, Y.; Ali, A.; Aqil, M. Status of terpenes as skin penetration enhancers. Drug Discov. 2007, 12, 1061-1067. [CrossRef] [PubMed]

116. Koul, O. Essential Oils as Green Pesticides: Potential and Constraints. Biopestic. Int. 2008, 4, $63-84$.

117. Tanzi, C.D.; Vian, M.A.; Giniès, C.; Elmaataoui, M.; Chemat, F. Terpenes as Green Solvents for Extraction of Oil from Microalgae. Molecules 2012, 17, 8196-8205. [CrossRef]

118. Marturano, V.; Bizzarro, V.; De Luise, A.; Calarco, A.; Ambrogi, V.; Giamberini, M.; Tylkowski, B.; Cerruti, P. Essential oils as solvents and core materials for the preparation of photo-responsive polymer nanocapsules. Nano Res. 2018, 11, 2783-2795. [CrossRef]

119. Mashwani, Z.-U.-R.; Khan, M.A.; Khan, T.; Nadhman, A. Applications of plant terpenoids in the synthesis of colloidal silver nanoparticles. Adv. Sci. 2016, 234, 132-141. [CrossRef]

120. Périno-Issartier, S.; Giniès, C.; Cravotto, G.; Chemat, F. A comparison of essential oils obtained from lavandin via different extraction processes: Ultrasound, microwave, turbohydrodistillation, steam and hydrodistillation. J. Chromatogr. A 2013, 1305, 41-47. [CrossRef]

121. Anastas, P.T.; Kirchhoff, M.M. Origins, Current Status, and Future Challenges of Green Chemistry. Acc. Chem. Res. 2002, 35, 686-694. [CrossRef]

122. Tucker, J.L. Green Chemistry, a Pharmaceutical Perspective. Org. Process. Res. Dev. 2006, 10, 315-319. [CrossRef]

(C) 2019 by the authors. Licensee MDPI, Basel, Switzerland. This article is an open access article distributed under the terms and conditions of the Creative Commons Attribution (CC BY) license (http://creativecommons.org/licenses/by/4.0/). 